\title{
Availability, affordability and costs of pediatric medicines in Mongolia
}

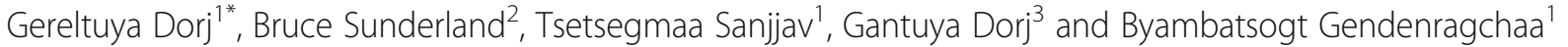

\begin{abstract}
Background: The Essential Medicines List for Children (EMLC) was developed by the World Health Organization (WHO) to assist member countries to achieve Millennium Development Goals (MDG). The Government of Mongolia has adopted a National Essential Drug List (NEDL) with the seventh update published in 2014. The objective of this study was to determine the accessibility, availability and costs of essential pediatric medicines in Mongolia.

Methods: A standardized methodology developed by the WHO and Health Action International (HAI) was employed to conduct a study on the availability, costs and affordability of pediatric medicines in Mongolia. A data collection tool collected information in regards to retail and wholesale availability and costs of essential pediatric medicines at pharmacy outlets during January and August of 2016.
\end{abstract}

Results: Availability of individual essential pediatric medicines varied across the country. The average availability of medicines was $72.6 \%$ in the public sector (9.1-100\%). Correspondingly, average availability of all selected medicines in the private sector was $76.7 \%$ (26.7-100\%). Lowest price medicines were 2.45 times higher than the international reference price (IRP) in the private sector and was 1.95 times higher in the public sector. The lowest cost medicines in the public sector were more affordable for all conditions. The least affordable treatment was estimated to be for respiratory tract infections, or otitis media using amoxicillin clavulanic acid, suspension costing up to 1.03 days wages.

Conclusion: Procurement, supply and distribution of essential pediatric medicines needs to be regularly investigated in order to identify the availability and costs of pediatric formulations in Mongolia.

Keywords: Essential medicines, Pediatric, Availability, Cost, Mongolia

\section{Background}

Mongolia is a country with a vast land of 1.56 million $\mathrm{km}^{2}$ with a population of three million. The country is divided into 21 provinces (aimags) and a metropolitan city (Ulaanbaatar). Ulaanbaatar city has 9 districts and they are sub-divided into 152 khoroos. Most of the population lives in urban areas and approximately $20 \%$ is nomadic. Unemployment was about $10.6 \%$ and the inflation rate was $0.9 \%$ in 2016 [1]. According to the World Bank, Mongolia is a lower middle income country with an estimated Gross Domestic Product (GDP) of United States Dollar (USD) 11.76 billion in 2015. About 14\% of the population lives on less than USD 1 per day [2]. The infant mortality rate was 15.3 per 1000 live births in 2014 [3].

\footnotetext{
* Correspondence: gereltuya@gmail.com

${ }^{1}$ School of Pharmacy and Biomedicine, Mongolian National University of Medical Sciences, S.Zorig Street, Ulaanbaatar 14210, Mongolia Full list of author information is available at the end of the article
}

\section{Pharmaceutical sector}

The Drugs Act of Mongolia was approved in 1998 with an aim of ensuring good quality, effective and safe drugs [4]. The Government subsequently promulgated the National Drug Policy of Mongolia (NDPM) in 2000 which was updated in 2014 [5]. Currently, 1496 pharmacies are operating in Mongolia of which $75 \%$ had one or two branches. There were 306 pharmacies working under the drug revolving fund (DRF) initiative [6].

The Essential Medicines List for Children (EMLc) [7] was developed by the World Health Organization (WHO) to assist member countries to achieve Millennium Development Goals(MDG) [8]. In December 2007, the WHO has also initiated the "Make Medicines Child Size" with a purpose of improving the accessibility of safe, effective and quality medicines for children by promoting awareness and action through research, regulatory measures and changes in government policy [9]. In accordance with

(c) The Author(s). 2018 Open Access This article is distributed under the terms of the Creative Commons Attribution 4.0 International License (http://creativecommons.org/licenses/by/4.0/), which permits unrestricted use, distribution, and 
WHO recommendations [10], the Government has adopted a National Essential Drug List since 1991 with regular updates, the seventh being completed in 2014 (7thEML). The NEDL contains 419 unique formulations, including 181 pediatric drugs [11]. There were 591 new drugs (salts or doses), 48 raw materials registered and the registration period was extended for a total of 428 drugs in 2014 [12].

In order to overcome barriers in supplying pediatric medicines and increase the accessibility to appropriate pediatric formulations, it is necessary to evaluate the availability and costs of essential medicines in pharmacy outlets and national medicines lists. Based on evidence and reliable scientific data, governments can apply necessary policy decisions and undertake interventions. Previous findings suggest that the availability and affordability of essential medicines needs to be improved in order to ensure accessibility to essential medicines in Mongolia [13]. However, no study has assessed the situation of essential pediatric medicines in Mongolia.

Therefore this study aimed to investigate the accessibility, availability and costs of essential pediatric medicines in Mongolia.

\section{Methods}

A standardized methodology developed by the WHO and Health Action International (HAI) [14] was applied to conduct the study. The validation of the WHO/HAI methodology has been reported in several studies previously $[15,16]$. A data collection tool was employed to collect availability information and retail and wholesale costs of essential pediatric medicines at pharmacy outlets during January and August of 2016. This timeline was selected due to the seasonal variables and high incidences of diseases in winter (January).

\section{Selection of pharmacy outlets}

Data collection included six aimags/regions/provinces, Ulaanbaatar city, Erdenet city, Khuvsgul aimag, Dornod aimag, Govi-Altai aimag and Selenge aimag. The capital city Ulaanbaatar was selected as the major urban centre of Mongolia and an additional five districts were selected randomly from those which could be reached within a day's travel from Ulaanbaatar city. The selection of study sites consistently included both urban and rural areas in all districts.

In each study area, five to ten pharmacy outlets were randomly selected from the list provided by the Health Development Centre, Ministry of Health and Sports of Mongolia.

The private sector sample included a total of 45 pharmacy outlets. Of those 11 private pharmacy outlets were located in public hospitals. Pharmacy outlets were selected based on active registration status and market volume size [17].

\section{Selection of medicines}

As specified in the "Better Medicines for Children Project", a core list of EMLc's representative of commonly used medicines for treatment of various pediatric conditions prevalent in low middle/income countries was adopted for the study. The core list included pediatric dosage forms for 23 formulations plus one device [18].

The study included all formulations on the core- list but excluded Artemether+lumefantrine as it is used for treatment of malaria which is not prevalent in Mongolia. Alternative formulations were registered in Mongolia were added into the list of core medicines and were investigated. A total of 30 medicines and one device were surveyed in this study (Table 1).

The highest and lowest costs for each medicine were surveyed and brand or generic medicines were recorded. Medicines provided at public hospitals were procured by a general procurement (tender) process, therefore only the availability was recorded.

\section{Data collection}

Trained data collectors visited pharmacy outlets and collected information regarding the cost, availability using a standardized data collection form and data were entered into a pre-programmed MS Excel Workbook provided as a part of the WHO/ HAI methodology. Data collectors provided the pharmacy outlets with written documentation describing the requirements for participation in the study. It was made clear that they could refuse to take part or terminate participation at any time. A verbal consent from the study participants was obtained prior to data collection.

\section{Availability of medicines}

Availability of medicines was recorded on the day of data collection by the data collector and checked by the supervisor. Data collectors worked in pairs, visited selected medicine outlets, collected data and completed the Medicine Prices Data Collection Forms. A data entry person entered data from the hard copy Medicine Price Data Collection Forms into the electronic survey, and was responsible for data validation by running the double entry program to ensure accuracy. The Workbook's auto checker was also used to assist in the verification process.

\section{Cross-country and international comparisons}

Reference prices, developed by the Management Sciences for Health (MSH), were used to facilitate national and international comparisons as these were found to be the most useful standard [19].

Cost comparison was completed across the country and internationally, median prices were expressed as ratios relative to a standard set of international reference prices (Eq. 1): 
Table 1 List of pediatric medicines surveyed in Mongolia

\begin{tabular}{|c|c|c|c|c|c|}
\hline No. & Disease & Medicine & Formulation & Strength & Target size pack \\
\hline 1 & Intestinal parasite & Albendazole & tablet & $200 \mathrm{mg}$ & 2 \\
\hline \multirow[t]{2}{*}{2} & Infectious disease & Amoxicillin & capsule & $250 \mathrm{mg}$ & 10 \\
\hline & Infectious disease & Amoxicillin & suspension & $125 \mathrm{mg}$ & $100 \mathrm{ml}$ \\
\hline 3 & & Aminophyllin & injection & $25 \mathrm{mg} / \mathrm{ml}$ & 1 vial \\
\hline \multirow[t]{3}{*}{4} & Infectious disease & Amoxicillin_Clavulanic acid & tablet & $125 \mathrm{mg}+125 \mathrm{mg}, \mathrm{tab}$ & 10 \\
\hline & Infectious disease & Amoxicillin_Clavulanic acid & suspension & $125 \mathrm{mg}+31.25 \mathrm{mg}$ & $100 \mathrm{ml}$ \\
\hline & Infectious disease & Amoxicillin_Clavulanic acid & suspension & $250 \mathrm{mg}+62.50 \mathrm{mg}$ & $100 \mathrm{ml}$ \\
\hline \multirow[t]{2}{*}{5} & Infectious disease & Azithromycin & capsule & $250 \mathrm{mg}$ & 6 \\
\hline & Infectious disease & Azithromycin & suspension & $200 \mathrm{mg} / 5 \mathrm{ml}$ & $100 \mathrm{ml}$ \\
\hline 6 & Asthma & Beclomethason & inhaler & 50 mg/day & 1 inhaler (200 doses) \\
\hline 7 & Infectious disease & Benzylpenicillin & injection & $600 \mathrm{mg}=1$ million IU & 1 vial \\
\hline \multirow[t]{2}{*}{8} & Seizure Disorder & Carbamazepine & tablet & $100 \mathrm{mg}$ & 20 \\
\hline & Seizure Disorder & Carbamazepine & suspension & $100 \mathrm{mg} / 5 \mathrm{ml}$ & $100 \mathrm{ml}$ \\
\hline 9 & Infectious disease & Cefazolin & injection & $1 \mathrm{~g}$, vial & 1 vial \\
\hline 10 & Infectious disease & Ceftriaxone & injection & 500 mg vial & 1 vial \\
\hline \multirow[t]{2}{*}{11} & Infectious disease & Chloramphenicol & tablet & $250 \mathrm{mg}$ & 10 \\
\hline & Infectious disease & Chloramphenicol & injection & $1 \mathrm{~g}$, vial & 1 vial \\
\hline 12 & Infectious disease & Chlorpheniramine & tablet & $4 \mathrm{mg}$ & 24 \\
\hline \multirow[t]{2}{*}{13} & Infectious disease & Clarithromycin & suspension & $125 \mathrm{mg} / 5 \mathrm{ml}$ & $100 \mathrm{ml}$ \\
\hline & Infectious disease & Clarithromycin & tablet & $125 \mathrm{mg}$ & 10 \\
\hline \multirow[t]{2}{*}{14} & Infectious disease & Cotrimoxazole & tablet & $\begin{array}{l}100 \mathrm{mg}+20 \mathrm{mg} \text { (also expressed } \\
\text { as } 400 \mathrm{mg}+80 \mathrm{mg} \text { ) }\end{array}$ & 10 \\
\hline & Infectious disease & Cotrimoxazole & suspension & & $100 \mathrm{ml}$ \\
\hline 15 & Seizure Disorder & Diazepam & tablet & $5 \mathrm{mg}$ & 10 \\
\hline 16 & Anemia & Ferrous salt & suspension & $30 \mathrm{mg} / 5 \mathrm{ml}$ & $100 \mathrm{ml}$ \\
\hline 17 & Fungal infection & Fluconazole & capsule & $150 \mathrm{mg}$ & 6 \\
\hline 18 & Infectious disease & Gentamycin & injection & $10 \mathrm{mg} / \mathrm{ml}$ & 1 vial \\
\hline \multirow[t]{2}{*}{19} & Pain/inflammation & Ibuprofen & tablet & $2 \mathrm{mg}$ & 24 \\
\hline & Pain/inflammation & Ibuprofen & suspension & & $100 \mathrm{ml}$ \\
\hline 20 & Tuberculosis & Isoniazide & tablet & $100 \mathrm{mg}$ & 56 \\
\hline \multirow[t]{2}{*}{21} & Pain & Morphine & tablet & $10 \mathrm{mg}$ & 56 \\
\hline & Pain & Morphine & oral solution & $10 \mathrm{mg} / 5 \mathrm{ml}$ & $100 \mathrm{ml}$ \\
\hline 22 & Dehydration & ORS & sachet & $500 \mathrm{ml}$ & 1 sachet \\
\hline \multirow[t]{4}{*}{23} & Pain/inflammation & Paracetamol & tablet & $250 \mathrm{mg}$ & 10 \\
\hline & Pain/inflammation & Paracetamol & suppository & $125 \mathrm{mg}$ & 10 \\
\hline & Pain/inflammation & Paracetamol & suppository & $250 \mathrm{mg}$ & 10 \\
\hline & Pain/inflammation & Paracetamol & suspension & $125 \mathrm{mg}$ & $100 \mathrm{ml}$ \\
\hline \multirow[t]{2}{*}{24} & Seizure Disorder & Phenobarbital & tablet & $30 \mathrm{mg}$ & 10 \\
\hline & Seizure Disorder & Phenobarbital & injection & $100 \mathrm{mg} / \mathrm{ml}$ & 1 vial \\
\hline \multirow[t]{2}{*}{25} & Seizure Disorder & Phenytoin & tablet & $50 \mathrm{mg}$ & 90 \\
\hline & Seizure Disorder & Phenytoin & suspension & $25 \mathrm{mg}, 30 \mathrm{mg} / 5 \mathrm{ml}$ & $500 \mathrm{ml}$ \\
\hline 26 & Infectious disease & Procain penicillin & injection & $1 \mathrm{~g}$, vial & 1 vial \\
\hline 27 & Asthma & Salbutamol & inhaler & $100 \mathrm{mcg}$ & 1 inhaler (200 doses) \\
\hline 28 & Xerophthalmia & Vitamin A & capsule & $100.000 \mathrm{IU}$ & 50 \\
\hline 29 & Anemia & Vitamin B6 & injection & $50 \mathrm{mg} / \mathrm{ml}$ & 1 vial \\
\hline 30 & Dehydration & Zinc & tablet & $20 \mathrm{mg}$ & 14 \\
\hline 31 & Spacer & Device & & & \\
\hline
\end{tabular}


Median Price Ratio = median local unit price

/international reference unit price

The exchange rate used to calculate MPRs was 1 USD $=1988.5$ Mongolian tugrigs as of the first day of data collection [20].

\section{Affordability}

As defined by the WHO, affordability is estimated using the daily wage of the lowest-paid unskilled government worker by determining the number of days' wages required to purchase selected courses of treatment for various conditions [18]. For the study, a total of seven conditions causing high pediatric mortality and morbidity in Mongolia and commonly used medicines were selected. These were; respiratory infections, urinary tract infections, otitis media, infections due to susceptible organisms, pneumonia, asthma, dehydration, pain and inflammation, seizure disorder and xerophthalmia. Treatment duration was defined as a full course of therapy for acute conditions whereas a supply of 30 days treatment duration was considered for chronic diseases [21].

\section{Results}

\section{Availability of medicines on the day of data collection}

There was a variation in availability of specific drugs however, a similar result was observed between the public and private sectors. The average availability of medicines was $72.6 \%$ in the public sector (range $(9.1-100 \%)$. Correspondingly, the average availability of all selected medicines in the private sector was 76.7\% (range 26.7-100\%) (Fig. 1).

\section{Public and private sector patient coats}

The lowest cost medicines were investigated and they were 1.95 times higher than the international reference price in the public sector. Generally, the lowest cost medicines were sold at 2.45 times higher than the international reference cost in the private sector. About one third of the medicines were costed at 1.85 (25 percentile) to 2.52 (75 percentile) times the international reference cost in the private sector with moderate cost variations existing across the sector (Table 2).

\section{Affordability of standard treatment regimens}

Affordability of standard treatment regimens recommended by the WHO were analyzed for selected pediatric medicines. Lowest cost medicines in the private sector were less affordable than in the public sector for most conditions. As indicated in Table 3, lowest cost medicines in the public sector were more affordable for all conditions, with standard treatment costing a day's wage or more. The least affordable treatment was estimated to be for respiratory tract infections or otitis media requiring amoxicillin clavulanic acid, suspension costing up to 1 . 03 days wages (Table 3 ).

\section{Discussion}

The study has evaluated the availability and affordability of essential pediatric medicines in Mongolia. The average availability of essential pediatric medicines was relatively good being on average over $70 \%$ in both sectors. Inconsistent and higher costs and lower affordability of medicines was found in the private sector. Pediatric formulations recommended in the WHO EMLc, including beclomethasone- inhaler [1], carbamazepine- suspension [1], diazepam-rectal solution [1], chloramphenicol -

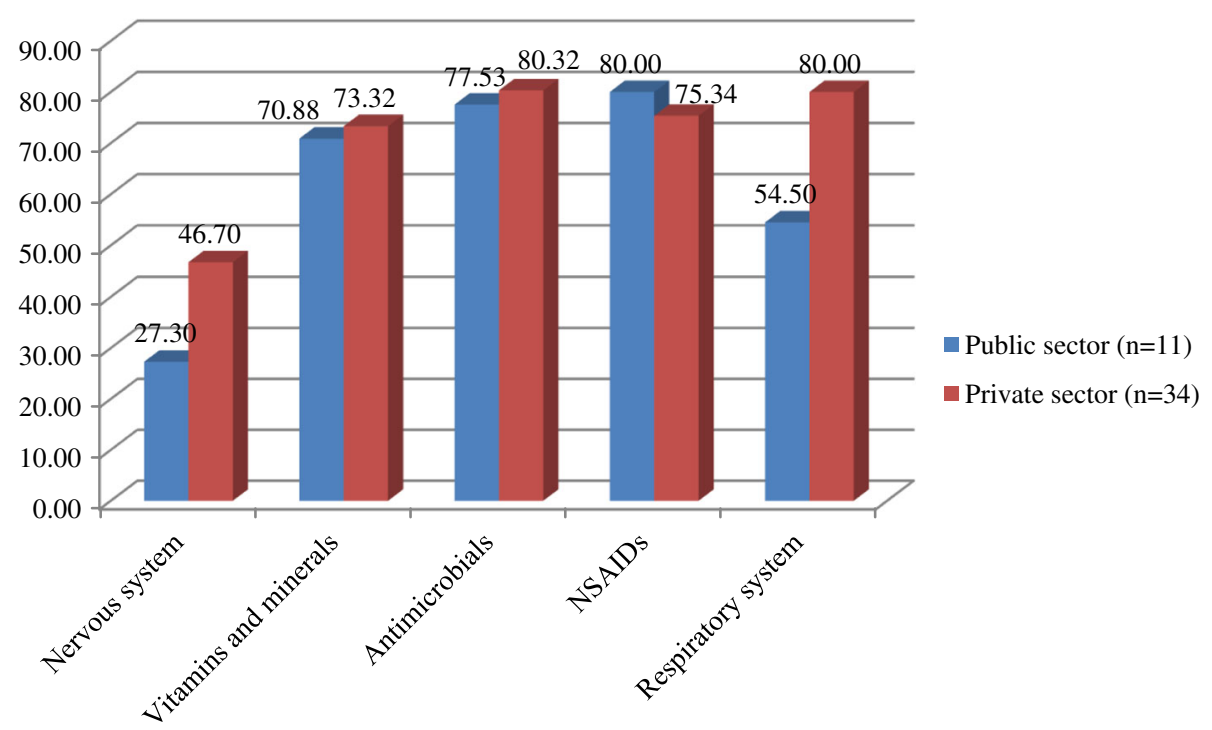

Fig. 1 Average availability of the lowest cost medicines in the public and private sectors 
Table 2 Public and private sector patient prices

\begin{tabular}{|c|c|c|c|c|}
\hline \multirow[t]{2}{*}{ Medicine } & \multirow[t]{2}{*}{ Formulation } & \multirow[t]{2}{*}{ Target size pack } & \multicolumn{2}{|c|}{ Lowest price medicines MPR (25th -75th percentile) } \\
\hline & & & Public sector & Private sector \\
\hline Albendazole & Tablet, $200 \mathrm{mg}$ & 2 & $3.83(3.83-5.74)$ & $3.83(3.83-31.91)$ \\
\hline Amoxicillin & Capsule, $250 \mathrm{mg}$ & 10 & $0.18(0.17-0.34)$ & $0.17(0.17-0.18)$ \\
\hline Amoxicillin & Suspension, $125 \mathrm{mg}$ & $100 \mathrm{ml}$ & $2.51(2.51-3.56)$ & $4.19(2.51-4.47)$ \\
\hline Aminophyllin & Injection, $25 \mathrm{mg} / \mathrm{ml}$ & 1 vial & - & - \\
\hline Amoxicillin_Clavulanic acid & Tablet, $125 \mathrm{mg}+125 \mathrm{mg}$, tab & 10 & $3.18(3.01-3.26)$ & $5.65(3.51-5.65)$ \\
\hline Amoxicillin_Clavulanic acid & Suspension, $125 \mathrm{mg}+31.25 \mathrm{mg}$ & $100 \mathrm{ml}$ & $2.03(1.85-2.40)$ & $4.59(1.85-4.59)$ \\
\hline Amoxicillin_Clavulanic acid & Suspension, $250 \mathrm{mg}+62.50 \mathrm{mg}$ & $100 \mathrm{ml}$ & $3.75(3.28-4.37)$ & $3.28(3.16-3.30)$ \\
\hline Azithromycin & Capsule, $250 \mathrm{mg}$ & 6 & $1.81(1.63-1.90)$ & $1.41(0.80-1.86)$ \\
\hline Azithromycin & Suspension, $200 \mathrm{mg} / 5 \mathrm{ml}$ & $100 \mathrm{ml}$ & $2.84(2.63-2.84)$ & $3.13(2.84-3.13)$ \\
\hline Beclomethason & Inhaler, $50 \mathrm{mg} /$ day & 1 inhaler (200 doses) & - & - \\
\hline Benzylpenicillin & Injection, 600 mg = 1 million IU & 1 vial & $0.89(0.82-0.93)$ & $1.41(0.80-1.90)$ \\
\hline Carbamazepin & Tablet, $100 \mathrm{mg}$ & 20 & $2.26(2.03-3.59)$ & $3.61(2.03-3.61)$ \\
\hline Carbamazepin & Suspension, $100 \mathrm{mg} / 5 \mathrm{ml}$ & $100 \mathrm{ml}$ & & \\
\hline Cefazolin & Injection, $1 \mathrm{~g}$, vial & 1 vial & $1.37(1.31-1.54)$ & $1.31(1.31-1.43)$ \\
\hline Ceftriaxone & Injection, 500 mg vial & 1 vial & $1.14(1.05-1.31)$ & $1.32(1.32-1.58)$ \\
\hline Chloramphenicol & Tablet, $250 \mathrm{mg}$ & 10 & $2.10(1.99-2.21)$ & $2.10(1.99-2.21)$ \\
\hline Chloramphenicol & Injection,1 g, vial & 1 vial & & \\
\hline Chlorpheniramine & Tablet, $4 \mathrm{mg}$ & 24 & $17.01(17.01-17.75)$ & $17.38(17.01-19.23)$ \\
\hline Clarithromycin & Suspension, $125 \mathrm{mg} / 5 \mathrm{ml}$ & $100 \mathrm{ml}$ & $1.14(1.05-1.33)$ & $1.33(1.33-1.39)$ \\
\hline Clarithromycin & Tablet, $125 \mathrm{mg}$ & 10 & $1.51(1.34-2.51)$ & $2.35(2.22-2.51)$ \\
\hline Cotrimexazol & Tablet, $100 \mathrm{mg}+20 \mathrm{mg}$ or $400 \mathrm{mg}+80 \mathrm{mg}$ & 10 & $3.56(3.56-3.86)$ & $3.96(3.56-11.48)$ \\
\hline Cotrimexazol & Suspension, $40 \mathrm{mg} / 5 \mathrm{ml}$ & $100 \mathrm{ml}$ & $0.41(0.38-0.42)$ & $0.42(0.38-0.42)$ \\
\hline Diazepam & Tablet, $5 \mathrm{mg}$ & 10 & $2.25(2.14-3.05)$ & $3.21(3.10-4.28)$ \\
\hline Ferrous salt & Suspension, $30 \mathrm{mg} / 5 \mathrm{ml}$ & $100 \mathrm{ml}$ & $0.53(0.51-0.55)$ & $0.65(0.59-0.69)$ \\
\hline Fluconazole & Capsule, $150 \mathrm{mg}$ & 6 & $0.70(0.70-0.73)$ & $3.02(0.70-3.91)$ \\
\hline Gentamycin & Injection, $10 \mathrm{mg} / \mathrm{ml}$ & 1 vial & $0.59(0.59-0.64)$ & $0.59(0.59-0.80)$ \\
\hline Ibuprofen & Tablet, $2 \mathrm{mg}$ & 24 & $12.38(11.73-12.38)$ & $12.38(10.42-14.66)$ \\
\hline Ibuprofen & Suspension, $100 \mathrm{mg} / 5 \mathrm{ml}$ & $100 \mathrm{ml}$ & $3.75(3.76-4.46)$ & $4.46(4.46-4.64)$ \\
\hline Isoniazide & Tablet, $100 \mathrm{mg}$ & 56 & - & - \\
\hline Morphine & Tablet, $10 \mathrm{mg}$ & 56 & - & - \\
\hline Morphine & oral solution, $10 \mathrm{mg} / 5 \mathrm{ml}$ & $100 \mathrm{ml}$ & - & - \\
\hline ORS & Sachet, $500 \mathrm{ml}$ & 1 sachet & $4.02(2.51-5.03)$ & $4.53(4.15-5.53)$ \\
\hline Paracetamol & Tablet, $250 \mathrm{mg}$ & 10 & - & - \\
\hline Paracetamol & Suppository, $125 \mathrm{mg}$ & 10 & $1.32(1.32-1.43)$ & $1.32(1.32-1.43)$ \\
\hline Paracetamol & Suppository, $250 \mathrm{mg}$ & 10 & $1.42(1.42-1.53)$ & $1.48(1.42-1.53)$ \\
\hline Paracetamol & Suspension, $125 \mathrm{mg} / 5 \mathrm{ml}$ & $100 \mathrm{ml}$ & $3.17(3.07-6.40)$ & $7.92(3.26-7.92)$ \\
\hline Phenobarbital & Tablet, $30 \mathrm{mg}$ & & - & - \\
\hline Phenobarbital & Injection, $100 \mathrm{mg} / \mathrm{ml}$ & 1 vial & - & - \\
\hline Phenytoin & Tablet, $50 \mathrm{mg}$ & 90 & - & - \\
\hline Phenytoin & Suspension, $25 \mathrm{mg}, 30 \mathrm{mg} / 5 \mathrm{ml}$ & $500 \mathrm{ml}$ & - & - \\
\hline Procain penicillin & Injection, $1 \mathrm{~g}$, vial & 1 vial & $0.06(0.06-0.07)$ & $0.08(0.06-0.11)$ \\
\hline Salbutamol & Inhaler, $100 \mathrm{mcg}$ & 1 inhaler (200 doses) & $2.26(1.45-2.51)$ & $2.51(2.49-2.58)$ \\
\hline Vitamin A & Capsule, $100.000 \mathrm{IU}$ & 50 & $1.60(1.60-2.26)$ & $2.45(1.60-2.52)$ \\
\hline Vitamin B6 & Injection, $50 \mathrm{mg} / \mathrm{ml}$ & 1 vial & $0.14(0.14-0.17)$ & $0.17(0.17-0.23)$ \\
\hline Zinc & Tablet, $20 \mathrm{mg}$ & 14 & $1.95(1.67-2.23)$ & $2.08(1.67-2.23)$ \\
\hline
\end{tabular}


Table 3 Affordability: Number of days' wages of the lowest paid government worker needed to purchase standard medications

\begin{tabular}{|c|c|c|c|c|}
\hline \multicolumn{3}{|c|}{ Disease condition and 'standard' treatment } & \multicolumn{2}{|c|}{$\begin{array}{l}\text { Day's wages to pay } \\
\text { for treatment }\end{array}$} \\
\hline Condition & Drug name, strength, dosage form & Treatment schedule & $\begin{array}{l}\text { LPM-Public } \\
\text { sector }\end{array}$ & $\begin{array}{l}\text { LPM-Private } \\
\text { sector }\end{array}$ \\
\hline $\begin{array}{l}\text { Respiratory Tract } \\
\text { Infections, UTIs }\end{array}$ & Amoxicllin Suspension $125 \mathrm{mg} / 5 \mathrm{ml}$ & Child up to 10 years: $125 \mathrm{mg}(=5 \mathrm{ml}) \times 3 \times 7$ days $=105 \mathrm{ml}$ & 0.38 & 0.65 \\
\hline $\begin{array}{l}\text { Respiratory Tract } \\
\text { Infections, Otitis Media }\end{array}$ & $\begin{array}{l}\text { Amoxicillin Clavulanic Acid } \\
\text { Suspension } 125-31.25 \mathrm{mg} / 5 \mathrm{ml}\end{array}$ & Child $1-6$ years: $125 \mathrm{mg}(=5 \mathrm{ml}) \times 3 \times 7$ days $=105 \mathrm{ml}$ & 0.46 & 1.03 \\
\hline $\begin{array}{l}\text { Respiratory Tract } \\
\text { Infections, Otitis Media }\end{array}$ & $\begin{array}{l}\text { Amoxicillin Clavulanic Acid } \\
\text { Suspension } 250-62.5 \mathrm{mg} / 5 \mathrm{ml}\end{array}$ & Child over 10 years: $250 \mathrm{mg}(=5 \mathrm{ml}) \times 3 \times 7$ days $=105 \mathrm{ml}$ & 0.85 & 1.00 \\
\hline Seizure Disorder & Carbamazepine tablet, $100 \mathrm{mg}$ & $\begin{array}{l}\text { Maintenance treatment: } 5 \mathrm{mg} / \mathrm{kg}^{*} 18 \mathrm{~kg}^{*} 3^{*} 30 \\
\text { days }=8100 \mathrm{mg} \text { or } 40.5 \text { tablets for } 1 \text { month }\end{array}$ & 0.34 & 0.54 \\
\hline $\begin{array}{l}\text { Infections due to } \\
\text { Susceptible Organisms }\end{array}$ & Ceftriaxone 500 mg vial & $\begin{array}{l}\text { Child under } 50 \mathrm{~kg} \text { : Maximum } 1 \mathrm{~g} \text { dailyx } 7 \\
\text { days }=7 \mathrm{~g} \text { or } 14 \text { vials }\end{array}$ & 0.11 & 0.15 \\
\hline $\begin{array}{l}\text { Infections due to } \\
\text { Susceptible Organisms }\end{array}$ & $\begin{array}{l}\text { Sulfamethoxazole+Trimethoprim } \\
(400 \mathrm{mg}+80 \mathrm{mg})\end{array}$ & $\begin{array}{l}18 \mathrm{~kg} \times 4 \mathrm{mg} / \mathrm{kg}=72 \mathrm{mg} \text { TMP } \times 2 \times 7 \text { days }=1008 \mathrm{mg} .126 \mathrm{ml} \\
\text { or } 12.6 \text { tablets total for } 7 \text { days }\end{array}$ & 0.09 & 0.30 \\
\hline Dehydration & $\begin{array}{l}\text { Oral Rehydration Solution, powder } \\
\text { to make } 500 \mathrm{ml}\end{array}$ & Moderate Dehydration; 75 ml/kgx18kg = $1350 \mathrm{ml}$ & 0.06 & 0.12 \\
\hline Pneumonia & Amoxicllin Suspension 125 mg/5 ml & Child up to 10 years: $125 \mathrm{mg}(=5 \mathrm{ml}) \times 3 \times 7$ days $=105 \mathrm{ml}$ & 0.38 & 0.65 \\
\hline Pain/inflammation & Paracetamol Suspension 24 mg/ml & 5 year old child: 15 mg/kgx18kgx4×3 = $3240 \mathrm{mg}=(130 \mathrm{~mL})$ & 0.28 & 0.28 \\
\hline Pain/inflammation & Ibuprofen suspension & 5 year old child: 15 mg/kgx18kgx4×3 = 3240 mg = $(130 \mathrm{~mL})$ & 0.67 & 0.79 \\
\hline Asthma & Salbutamol inhaler $100 \mathrm{mcg} /$ dose & 1 inhaler 200 doses & 0.38 & 0.65 \\
\hline Xerophthalmia & Vitamin A 50,000 units & Child $1-12$ years: 200,000 units $\times 3$ doses & 0.12 & 0.18 \\
\hline
\end{tabular}

*LPM- Lowest Price Medicine

injection [1], isoniazid- scored tablet [1], morphine-oral solution [1], phenobarbital -injection [1], phenytoin- chewable tablet [1] spacer- device [1] were not assessable, because they are not registered and unavailable in Mongolia. Similarly, lack of appropriate dosage formulations for phenobarbital, phenytoin, carbamazepine, diazepam (rectal solution) were reported in a study at a tertiary care hospital with 2000 beds, in Western India [22].

This identifies a lack of some child friendly formulations available which could be related to the difficulty of obtaining the product if it was not locally manufactured. A study has assessed the availability of essential pediatric medicines in China and reported that a dearth of registered pediatric medicines may be attributed to multiple factors including the manufacturers' lack of motivation to produce because of low demand or small profit, less effective bidding and procurement systems for pediatric medicines, hospitals' preferences for higher-priced medicines, inappropriate drug selection and weak health and supply systems [15, 23]. Additionally, insufficient knowledge or application of clinical standards and protocols [24], and exclusion from central procurement lists due to high cost may be other reasons for unavailability [25].

Amongst the surveyed medicines, originator brands were rarely available in both sectors, mainly due to high cost and the Government's effort to improve and promote the use of generic medicines in Mongolia [5]. The study results were consistent with previous studies assessing availability and affordability of essential medicines for adults $[13,16,26-28]$. These studies have shown that availability was lower in the public sector when compared to the private pharmacies.

Lack of child friendly formulations was observed in this study. Chloramphenicol injection, morphine, beclomethasone were not available in two sectors. According to other studies, similar findings have been reported $[23,29]$. Medicines to treat seizure disorders (phenobarbital, phenytoin) and pain (morphine) were not found in any of the surveyed pharmacy outlets. This is due to the legislation restricting the use of narcotic and psychotropic drugs [4], only a few pharmacy outlets with special permission are eligible to stock them.

Diseases of the digestive system, including diarrhea was one of the main reasons for pediatric mortality and morbidity in Mongolia. Oral rehydration powders were available in most of pharmacy outlets in both sectors. However, dispersible tablets of Zinc as recommended in the EMLc, were available in only half of the surveyed sites $(50.6 \%)$. Evidence based data suggest that zinc is beneficial for treatment of pediatric diarrhea for children aged 6 months or older [30].

Paracetamol (acetaminophen) has a unique role in children because it is the first-line choice for the treatment of both fever and pain. When used in the recommended doses, it has few side effects and is remarkably well tolerated [31]. However, the recommended pediatric 
dose tablet was not available in any of the surveyed pharmacies. Instead, dispensers (pharmacist or pharmacy technician) would dispense adult dose tablet (500 mg) and advise to cut the tablet into half when a pediatric dose was prescribed. Clinical data proves that in overdose, paracetamol is hepatotoxic [31].

The affordability of lowest cost medicines was compared across the country. The pediatric essential medicines were generally less affordable in the private sector and costed more than the recommended international reference prices.

Mongolia is country with seasonal variations, with winter being very long and harsh. During this time, most pediatric conditions are associated with respiratory infections. Pneumonia and other respiratory infections are reported to be the main reason for children's hospitalization in Mongolia [3]. Empiric treatment with appropriate antibiotics for respiratory infections, including pneumonia is crucial in the reduction of mortality from pneumonia [32]. Treatment of pneumonia with amoxicillin suspension would cost more than a half day's wage, whereas for other respiratory infections (otitis media), the cost of treatment would be 1 day's wage.

When compared to other countries, this result is comparably low [29]. Considering the fact that $14 \%$ of Mongolians live on less than USD 1 per day [2], treatments seem to be too expensive. On the other hand, treatment cost reflects medicines cost only, excluding any additional consultation or diagnostic costs. Additionally, treatment was estimated only for one child, indicating that families with more children and their treatment would endure an overwhelming cost. Similar to previous findings, essential medicines are often not affordable for many populations [13, 16, 27, 33].

\section{Limitations}

The study has several limitations that are consistent with previous surveys. The WHO/HAI methodology did not assess the therapeutic alternatives or alternative dosage forms. The study results reflect the status of availability and cost based on the day of data collection. They do not necessarily reflect the monthly or yearly availability of essential pediatric medicines at the national level or individual pharmacy outlets. In addition, the median cost ratio was estimated using the supplier cost. Although, when the supplier cost was not available, buyer costs were used to calculate the median international reference cost. Substituting the supplier with buyer cost could result in inaccurate prices and therefore influence the true median price [15].

On the other hand, the study has utilized a previously validated methodology using a standardized way to evaluate the availability and costs of essential pediatric medicines in the country [34]. Furthermore, training and using multiple checkpoints have improved the quality of data collection, data entry and interpretation.

\section{Conclusion}

The findings of this study can serve as basic data to develop and revise the National Policy in order to improve the accessibility and availability of essential pediatric medicines in Mongolia. Furthermore, control, monitoring and comparing pediatric medicines costs not just across the country but also at the international level would help to increase transparency of different tasks including registration, procurement and reimbursement decision making procedures. A detailed investigation regarding the prescribing of pediatric medicines should be completed to identify the challenges and barriers. Finally, the procurement, supply and distribution of essential pediatric medicines needs to be examined in order to identify the lack of availability and higher costs of some essential pediatric medicines in Mongolia.

\section{Abbreviations}

DRF: Drug Revolving Fund; EMLc: The Essential Medicines List for Children; GDP: Gross Domestic Product; HAl: Health Action International; IRP: International Reference Price; MDG: Millennium Development Goals; NDPM: National Drug Policy of Mongolia; NEDL: National Essential Drug List; NSAID: Non steroidal anti-inflammatory drugs; WHO: World Health Organization

\section{Acknowledgements \\ Authors would like to acknowledge all pharmacists consenting to participate as well as Dr. Marg Ewen, Health Action International, who provided necessary materials for data collection and analysis.}

Availability of data and materials

Please contact author for data requests.

\section{Authors' contributions}

GD, BS, TS, BG - conceived of the study, and participated in its design and coordination and helped to draft the manuscript. All authors have read and approved the manuscript.

\section{Ethics approval and consent to participate}

The study protocol was approved by the Human Ethics Committee, Mongolian National University of Medical Sciences (2016-01). All participants were informed about the study protocol including objectives, methodology and expected outcomes prior the study. A verbal informed consent was obtained from all participants.

\section{Competing interests}

We declare that there was no funding for publication of this manuscript and we have no financial or non-financial competing interests.

\section{Publisher's Note}

Springer Nature remains neutral with regard to jurisdictional claims in published maps and institutional affiliations.

\section{Author details \\ ${ }^{1}$ School of Pharmacy and Biomedicine, Mongolian National University of Medical Sciences, S.Zorig Street, Ulaanbaatar 14210, Mongolia. ${ }^{2}$ School of Pharmacy, Bentley, Curtin University, GPO Box U1987, Bentley, WA 6845, Australia. ${ }^{3}$ School of Public Health, Mongolian National University of Medical Sciences, S. Zorig Street, Ulaanbaatar 14210, Mongolia.}

Received: 11 December 2016 Accepted: 26 April 2018 Published online: 02 May 2018

\section{References}

1. National Statistics Office of Mongolia. National Statistics Office of Mongolia., 2016.

2. World Bank. Poverty Rate in Mongolia Estimated at 29.6 Percent. 2016. Available from http://www.worldbank.org/en/news/press-release/2017/10/ 17/2016-poverty-rate-in-mongolia-estimated-at-296-percent. 
3. Health Development Centre of Mongolia. Health indicators of Mongolia 2014

4. Ministry of Health Mongolia. The drugs act of Mongolia 1998.

5. Ministry of Health Mongolia. National Drug Policy of Mongolia, 2014.

6. Ariuntuya S, Narantuya Kh, Davaajargal S, Enkhjargal TS, Unurtsetseg T. Health Indicators of Mongolia 2014. Ulaanbaatar Mongolia Health Department of Mongolia.

7. World Health Organization. Priority life-saving medicines for women and children. Geneva: WHO; 2012. Available.

8. Murray CJ, Laakso T, Shibuya K, Hill K, Lopez AD. Can we achieve millennium development goal 4? New analysis of country trends and forecasts of under-5 mortality to 2015. Lancet. 2007;370(9592): 1040-54. Available.

9. World Health Organization. Make medicines child size, 2010.

10. World Health Organization. Promoting rational use of medicines: Core components, 1977.

11. Ministry of Health Mongolia. The National Essential Drug List of Mongolia (7th revision) 2014.

12. Ministry of Health and Sports Mongolia. Pharmaceutical sector indicators of Mongolia, 2014

13. Munkhdelger Ch. Medicine Prices, Availability, Affordability and Price Components in Mongolia. 2013 [cited 1st of April ]. Available from: http:// haiweb.org/wp-content/uploads/2015/07/Mongolia-Report-Pricing-Surveys.pdf.

14. World Health Organization. Health Action International. Medicine prices: a new approach to measurement. Working draft for field testing and revision. WHO/EDM/PAR/2003.2), 2003. Available from: http://www.haiweb.org/ medicineprices/manual/manuals/MedicinePrices.pdf; 2003.

15. Cameron A, Ewen M, Ross-Degnan D, Ball D, Laing R. Medicine prices, availability, and affordability in 36 developing and middle-income countries: a secondary analysis. Lancet. 2009;373(9659):240-9. Available.

16. Cameron A, Roubos I, Ewen M, Mantel-Teeuwisse AK, Leufkens HG, Laing $\mathrm{RO}$. Differences in the availability of medicines for chronic and acute conditions in the public and private sectors of developing countries. Bull World Health Organ. 2011;89:412-21. Available.

17. Ministry of Health Mongolia. Health indicators of Mongolia 2015.

18. World Health Organization. Overview of methods for medicines availability and pricing surveys: better medicines for children project., 2009.

19. Management Sciences for Health. International drug price Indicator 2003.

20. State Bank of Mongolia. Currency exchange rate 2016.

21. Health Action International: World Health Organization. Meassuring medicine prices, availability, affordability and price components., 2002

22. Desai M, Jain K, Shah S, Dikshit R. Availability of pediatric medicines and their perception among prescribers at a tertiary care teaching hospital. Available; 2012

23. Chen W, Tang S, Sun J, Ross-Degnan D, Wagner AK. Availability and use of essential medicines in China: manufacturing, supply, and prescribing in Shandong and Gansu provinces. BMC Health Serv Res. 2010;10(1):1. Available.

24. Chisholm D, David B. Evans. Improving health system e ciency as a means of moving towards universal coverage, 2010.

25. Robertson J, Forte G, Trapsida J-M, Hill S. What essential medicines for children are on the shelf? Bull World Health Organ. 2009;87(3):231-7. Available.

26. Anson A, Ramay B, de Esparza AR, Bero L. Availability, prices and affordability of the World Health Organization's essential medicines for children in Guatemala. Glob Health. 2012;8(1):22. Available.

27. Mendis S, Fukino K, Cameron A, Laing R, Filipe Jr A, Khatib O, et al. The availability and affordability of selected essential medicines for chronic diseases in six low-and middle-income countries. Bull World Health Organ. 2007:85(4):279-88. Available.

28. van Mourik MS, Cameron A, Ewen M, Laing RO. Availability, price and affordability of cardiovascular medicines: a comparison across 36 countries using WHO/HAl data. BMC Cardiovasc Disord. 2010;10(1):25. Available.

29. Anson A, Ramay B, de Esparza AR, Bero L. Availability, prices and affordability of the World Health Organization's essential medicines for children in Guatemala. Glob Health. 2012;8(1):1. Available.

30. Lazzerini M, Ronfani L. Oral zinc for treating diarrhoea in children. The Cochrane Library. 2008; Available.

31. Cranswick N, Coghlan D. Paracetamol efficacy and safety in children: the first 40 years. Am J Ther. 2000;7(2):135-42. Available.

32. World Health Organization. Technical bases for the WHO recommendations on the management of pneumonia in children at first-level health facilities. 1991; Available.
33. Niëns LM, Cameron A, Van de Poel E, Ewen M, Brouwer WB, Laing R. Quantifying the impoverishing effects of purchasing medicines: a crosscountry comparison of the affordability of medicines in the developing world. PLoS Med. 2010;7(8):e1000333. Available.

34. Madden JM, Meza E, Ewen M, Laing RO, Stephens P, Ross-Degnan D. Measuring medicine prices in Peru: validation of key aspects of WHO/HAl survey methodology. Rev Panam Salud Publica. 2010;27(4):291-9. Available.

\section{Ready to submit your research? Choose BMC and benefit from:}

- fast, convenient online submission

- thorough peer review by experienced researchers in your field

- rapid publication on acceptance

- support for research data, including large and complex data types

- gold Open Access which fosters wider collaboration and increased citations

- maximum visibility for your research: over $100 \mathrm{M}$ website views per year

At BMC, research is always in progress.

Learn more biomedcentral.com/submissions 